\title{
DETECTION OF EQUINE ARTERITIS VIRUS IN THE SEMEN OF STALLIONS IN THE REPUBLIC OF SERBIA
}

\author{
LAZIĆ Sava ${ }^{1 *}$, LUPULOVIĆ Diana ${ }^{1}$, POLAČEK Vladimir ${ }^{1}$, VALČIĆ Miroslav ${ }^{2}$, \\ LAZIĆ Gospava ${ }^{1}$, PAŠAGIĆ Enisa ${ }^{3}$, PETROVIĆ Tamaš ${ }^{1}$
}

\footnotetext{
${ }^{1}$ Scientific Veterinary Institute „Novi Sad“, Rumenački put 20, 21000 Novi Sad, Republic of Serbia; ${ }^{2}$ Faculty of Veterinary Medicine, University of Belgrade, Bulevar oslobođenja 18, 11000 Beograd, Republic of Serbia; ${ }^{3}$ Veterinary Pharmacy „Pet Svet 024“, Joa Lajoš 5, 24000 Subotica, Republic of Serbia;
}

(Received 5 May; Accepted 12 October 2015)

\begin{abstract}
The results on serological testing of blood sera from stallions and mares used for breeding and the presence of the viral genome of Equine Arteritis Virus (EAV) in stallion semen are presented. The blood and semen samples were taken from a horse stable on the territory of the Republic of Serbia during 2012, 2013 and 2014. Detection of anti-EAV specific antibodies in blood sera was performed by the virus neutralization test (VNT), and identification of EAV genome RNA in stallion semen was done by reverse-transcriptase polymerase chain reaction (RT-PCR). In 2012, high seroprevalence of EAV was detected in the investigated stable. In total, $45 \%$ and $65 \%$ of stallions and mares reacted positive, respectively, and the antibody titre values ranged between 2 and $10 \log _{2}$. High seroprevalence was confirmed in the same animals again in 2013. Out of two stallions tested semen samples in 2013, the viral genome was detected by RT-PCR in 3 examined semen samples from a seropositive stallion, while EAV was not detected in 3 semen samples of a seronegative stallion. During 2014, 11 semen samples were collected from two seropositive stallions. Again, the presence of EAV was confirmed by RT-PCR in all 8 semen samples originating from the same stallion with the EAV genome positive semen result in 2013, whereas the virus was not detected in semen samples originating from the second anti-EAV antibody positive stallion. The presence of EAV-specific antibodies was confirmed in the blood sera of the mares inseminated with the semen of seropositive stallions in 2012 and 2013.
\end{abstract}

Key words: breeding stallions, semen, Equine arteritis virus, RT-PCR, seroprevalence, virus neutralization

\section{INTRODUCTION}

Equine viral arteritis (EVA) is an infectious disease that can affect all horse categories, including foals, colts, mares, stallions and geldings. The causative agent is Equine

Corresponding author: e-mail: lazic@niv.ns.ac.rs 
arteritis virus (EAV) from the family Arteriviridae. EAV is an enveloped, spherical virus with a diameter of $50-70 \mathrm{~nm}$. The genome is a single-stranded RNA with approximately $12.7 \mathrm{~kb}$ in length [1]. The virus was first isolated in 1953 in the USA [2] and since then the disease has been reported in several countries on almost all continents. Only Japan, Iceland and New Zealand are considered free of EVA [3]. Virus transmission between horses occurs via the respiratory and genital system during 7-14 days of the acute stage of the disease. EAV is shed in the secretions of infected animals and transmitted to other horses via aerosol particles; however, for the occurrence of the infection, direct and close contact between horses is usually required [4,5]. The virus is also shed in urine, aborted foetuses, amniotic fluid and placenta or other excreta of acute infected horses and can be transmitted to other animals by direct contact with the infective material. Virus transmission through the semen of persistently infected stallions is a significant route of infection, since EAV is frequently present in the semen.

Most common clinical signs of the disease include increased body temperature that may reach even $41.8^{\circ} \mathrm{C}$ and can persist during a period of 2 to 9 days [6]. Progressive bronchopneumonia and diverse forms of enteritis develop in foals and younger horses (colts), whereas young foals (aged 1-3 months) can manifest symptoms of bronchopneumonia and enteritis at the same time, which rapidly develop to a progressive "pneumo-enteric" syndrome [7]. EVA infection can include oedema - predominantly of the eyelids, distal parts of the limbs and abdomen, as well as oedema of the preputium and scrotum in stallions. Abortions in pregnant mares are one of the most important clinical signs of the disease. The number of abortions can vary from single ones to massive epidemics, when up to $70 \%$ of pregnant mares in the stable can miscarry [6,8]. Abortions commonly occur between the $3^{\text {rd }}$ and $10^{\text {th }}$ month of gestation as a result of viral infection of the foetus and amniotic membrane, which can cause foetal death and consequently abortion. However, detection of EAV-specific antibodies in newborn foals, before uptake of the colostrum, indicates that foetal infection does not necessarily has a lethal outcome, i.e., foetal death and abortion [8]. In adult horses, EVA infection can be presented in the subclinical form [9] without obvious clinical signs and the occurrence of abortion in mares [10], which is determined by the immune status of the infected animal and by biological properties of the virus [6]. Stallions can be infected chronically, often without clinical signs of the disease, but the virus targets the cells of the ductus deferens, thus enabling shedding and dissemination of the virus via the ejaculate of carrier stallions [6]. Even up to $70 \%$ of stallions, after the infection can remain persistently infected for lifetime [11].

The diagnosis of EVA is based on laboratory examination. Detection of anti-EAV specific antibodies in the blood sera is considered most important for the diagnostic examination and is performed by the virus neutralization test (VNT) or ELISA. The first anti-EAV antibodies can be detected 7-14 days after infection. The highest levels of antibodies are detectable in the period 2-4 months post infection, and they can persist for 3 or more years [6,12]. Antibody titre values higher than $2 \log _{2}$ are considered 
positive in VNT [13]. For diagnosis of EVA infection the following methods for virus detection in clinical samples are also very important: virus isolation in susceptible cell cultures (RK-13), molecular techniques (RT-PCR) or immunohistochemical examination [14]. A certain attention in laboratory testing should be paid to stallions. During the past 20 years, different molecular methods have been developed with the aim of a rapid and effective virus detection in stallion semen, based on reverse transcriptase-polymerase chain reaction (RT-PCR) [6,8,11,15].

In the Republic of Serbia, the diagnosis of EVA infection has been introduced in 2002, and covered only imported horses during the quarantine period. Later on, most probably because of increasing awareness of the importance of this disease, the horse breeders took the initiative towards serological testing of both stallions and mares before mating [16]. So far, a vaccination program against EAV has not been implemented in the Republic of Serbia.

\section{MATERIAL AND METHODS}

\section{Animals}

The study encompassed horses at a horse stable with an annual raising capacity of 60 Lipizzaner breed horses of all categories. In order to detect the presence and prevalence of EVA infection in the examined stable, blood samples from all mares and stallions that are used for breeding were collected in 2012 and 2013, as well as blood and semen samples from 3 stallions which semen is mostly used for artificial insemination were collected during 2013 and 2014. At this horse stable, the only method for fertilization is artificial insemination takes place during spring period (April-May). In addition, analysis of the health status of all horses on this horse stable for the period of last 5 years was performed. This analysis was performed according to anamnestic data obtained from the veterinarians and farm management and by evaluating health records data of all stallions and mares included in this research. To provide a clear overview of collected samples, the data on sampling periods, number, origin and type of samples are presented in Table 1.

\section{Blood samples}

Blood was taken from 9 stallions and 20 mares in October 2012, and again in October 2013 from 7 stallions and 14 mares from the same group of animals. Blood was taken by puncture of the jugular vein and collected into blood collection tubes. Blood samples from 3 stallions, which are used for artificial insemination, were additionally collected at the same time when semen sampling in 2013 and 2014. 
Table 1. Data on sampling period, origin and type of samples

\begin{tabular}{|c|c|c|c|c|c|c|}
\hline \multirow{3}{*}{ Tested animals } & \multicolumn{6}{|c|}{ Samplings } \\
\hline & \multicolumn{2}{|c|}{2012} & \multicolumn{2}{|c|}{2013} & \multicolumn{2}{|c|}{2014} \\
\hline & blood & semen & blood & semen & blood & semen \\
\hline Stallion № 1 & October & ND & $\begin{array}{c}24.04 . \\
\text { October }\end{array}$ & $\begin{array}{l}24 / 04 / \\
25 / 04 / \\
26 / 04 /\end{array}$ & $09 / 05 /$ & $\begin{array}{c}09 / 05 / \\
17 / 05 / \\
19 / 05 / \\
22 / 05 / \mathrm{A} \\
22 / 05 / \mathrm{B} \\
23 / 05 / \mathrm{A} \\
23 / 05 / \mathrm{B} \\
24 / 05 /\end{array}$ \\
\hline Stallion № 2 & October & ND & $\begin{array}{c}24.04 . \\
\text { October }\end{array}$ & $\begin{array}{l}24 / 04 / \\
25 / 04 / \\
26 / 04 /\end{array}$ & ND & ND \\
\hline Stallion № 3 & October & ND & October & ND & $25 / 04 /$ & $\begin{array}{l}25 / 04 / \\
26 / 04 / \\
27 / 04 /\end{array}$ \\
\hline Stallions from № 4 to № 7 & October & ND & October & ND & ND & ND \\
\hline Stallions № 8 and № 9 & October & ND & ND & ND & ND & ND \\
\hline Mares from № 1 to № 14 & October & $\mathrm{NA}$ & October & $\mathrm{NA}$ & ND & NA \\
\hline Mares from № 15 to № 20 & October & NA & ND & NA & ND & NA \\
\hline
\end{tabular}

ND - not done; NA - not applicable; A - Semen sample collected in the morning; B - Semen sample collected in the evening

\section{Semen samples}

Semen samples were collected during the mating season using an artificial vagina (Missouri model, Germany). Immediately after collecting the ejaculate, a volume of $3 \mathrm{ml}$ semen sample was poured from the collection tube into sterile tubes and stored in a freezer at $-20^{\circ} \mathrm{C}$ until testing. For each sampling a sterile lining and sterile collection tube were used. In April 2013, 6 semen samples were collected from two stallions (3 samples per stallion with a 24-hour interval). Serological examination performed in 2012 revealed that one stallion (stallion № 1) was seropositive with a high antiEAV antibody titre, while the second one was seronegative (stallion № 2). During May 2014 (between $9^{\text {th }}$ and $15^{\text {th }}$ May), 8 semen samples were collected consecutively from the same seropositive stallion (stallion № 1) whose semen was previously tested in 2013. The samples were collected at different time intervals, of sequential semen collection for artificial insemination of mares. During April 2014, 3 semen samples were collected with 24-hour intervals from the second stallion that was seropositive (stallion № 3) in 2012 and 2013. 


\section{Virus neutralization test (VNT)}

For the detection of antibodies against EAV in blood serum samples virus neutralization test (VNT) was used, according to the procedure prescribed by OIE Terrestrial Manual, Chapter 2.5.10 (2008). Virus neutralization test was performed by using rabbit-kidney cell line RK-13 (ATCC-CCL-37) and Bucyrus strain of EAV (CVL Bucirus, APHIS, NVSL, Ames, USA). The determined antibody titre values are expressed as binary logarithm to base $2\left(\log _{2}\right)$.

\section{Reverse transcriptase-polymerase chain reaction (RT-PCR)}

RNA was extracted from each of 17 (6, 3+3, from 2 stallions in 2013, and 8 and 3 samples from 2 stallions in 2014) homogenized/lysed native stallion semen samples using a commercial kit (Qiagen Viral RNA Mini Kit, QIAGEN, Germany) according to manufacturer's instruction. Native semen from the seronegative stallion, artificially contaminated with the Bucyrus reference strain of EAV (100 TCID $\left.{ }_{50} / 0.1 \mathrm{~mL}\right)$, was used as a positive control for RNA extraction and RT-PCR, and the same native semen from a seronegative stallion, not artificially contaminated, was used as the negative control. The obtained RNA extracts were further amplified by reverse transcription - polymerase chain reaction (RT-PCR) using primers: forward EAV7.53F: 5'-GGCGACAGCCTACAAGCTACA-3' and reverse EAV7.256R: 5'-CGGCATCTGCAGTGAGTGA-3' that target virus nucleocapsid gene described by Balasuriya et al. (2002). One-step RT-PCR amplification was done using commercial kit Qiagen OneStep RT-PCR kit chemistry (QIAGEN, Germany) according to manufacturer's instruction and with small modifications. Briefly, the amplification reaction was carried out in a volume of $25 \mu \mathrm{L}$ containing $13.5 \mu \mathrm{L}$ of nuclease-free water, $5 \mu \mathrm{L}$ of $5 \mathrm{x}$ PCR buffer, $1 \mu \mathrm{L}$ of dNTP mix (containing $10 \mathrm{mM}$ of each dNTP), $0.25 \mu \mathrm{L}$ of stock solution of $100 \mu \mathrm{M}$ of each primer, $1 \mu \mathrm{L}$ of one step RT-PCR enzyme mix and $4 \mu \mathrm{L}$ of RNA template. The amplification conditions (Thermocycler Gradient, Eppendorf, Germany) were as follows: reverse transcription stage at $50^{\circ} \mathrm{C}$ for $30 \mathrm{~min}$, followed by an initial PCR activation step at $95^{\circ} \mathrm{C}$ for $15 \mathrm{~min}, 40$ cycles of $95^{\circ} \mathrm{C}$ for $30 \mathrm{~s}, 55^{\circ} \mathrm{C}$ for $60 \mathrm{~s}, 72^{\circ} \mathrm{C}$ for $60 \mathrm{~s}$, and a final extension at $72^{\circ} \mathrm{C}$ for 10 minutes. Specific PCR product of 204 bp was detected and visualised by electrophoresis on 1.5 agarose gel stained with ethidium bromide.

\section{Virus isolation}

Virus isolation was performed using the 6 -well microplates. The microplate wells were filled with $3 \mathrm{ml}$ of RK-13 cell culture suspension (about 105 cells $/ \mathrm{mL}$ ). After 24 hour incubation, semen samples were inoculated onto the $75 \%$ confluent cell monolayer, and the EAV isolation was performed according to the procedure recommended by OIE Terrestrial Manual, Chapter 2.5 .10 (2013). Cytopathogenic effect has not been observed after 3 subsequent blind passages (6-day each). Additionally, EAV presence in the cell supernatant of the third blind passages was established by RT-PCR testing. 


\section{RESULTS}

The results of anti-EAV antibodies in the blood sera examined by VNT and detection of EAV in the semen tested by RT-PCR are presented in tables and figures, respectively.

Table 2. Detected antibody titre values in blood sera of stallions and mares, used for breeding in 2012 and 2013.

Table 2. Results of testing horse blood sera for the presence of anti-EAV antibodies

\begin{tabular}{ccccccccccccccc}
\hline \multirow{2}{*}{$\begin{array}{c}\text { Year of } \\
\text { research }\end{array}$} & Horse & $\begin{array}{c}\text { No. of } \\
\text { category }\end{array}$ & \multicolumn{8}{c}{ Nosted } \\
\cline { 3 - 14 } & horses & $\mathbf{0}$ & $\mathbf{1}$ & $\mathbf{2}$ & $\mathbf{3}$ & $\mathbf{4}$ & $\mathbf{5}$ & $\mathbf{6}$ & $\mathbf{7}$ & $\mathbf{8}$ & $\mathbf{9}$ & $\mathbf{1 0}$ \\
\hline \multirow{2}{*}{2012} & Stallion & 9 & 5 & 0 & 2 & 0 & 0 & 0 & 0 & 1 & 0 & 1 & 0 \\
& Mare & 20 & 7 & 1 & 0 & 0 & 3 & 4 & 3 & 1 & 0 & 0 & 1 \\
2013 & Stallion & 7 & 3 & 0 & 2 & 0 & 0 & 1 & 0 & 0 & 1 & 0 & 0 \\
& Mare & 14 & 3 & 0 & 1 & 1 & 2 & 2 & 1 & 3 & 1 & 0 & 0 \\
\hline
\end{tabular}

Out of 9 stallions and 20 mares examined during 2012, the presence of anti-EAV antibodies was detected in the blood sera of 4 stallions and 12 mares. Antibody titre values in the stallions were $2 \log _{2}$ in 2 stallions, $7 \log _{2}$ in one and $9 \log _{2}$ in one stallion. In mares, the observed antibody titre values were 4, 5, 6 and $7 \log _{2}$ in 11 mares and 10 $\log _{2}$ in one mare.

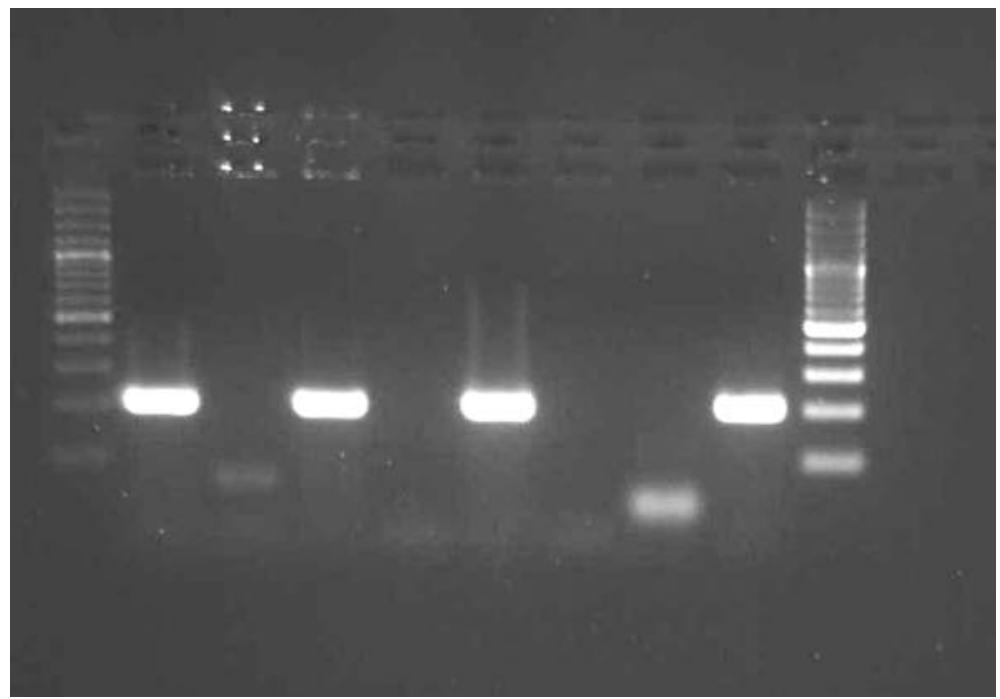

Figure 1. RT-PCR products from semen samples (from left to right): 1. PCR marker, 100 bp; 2. Semen of seropositive stallion (stallion № 1) collected: 24/04/2013; 3. Semen of seronegative stallion (stallion № 2), collected: 24/04/2013; 4. Semen of stallion № 1, collected: 25/04/2013; 5. Semen of stallion № 2, collected: 25/04/2013; 6. Semen of stallion № 1, collected: 26/04/2013; 7. Semen of stallion № 2, collected: 26/04/2013; 8. negative control (water), 9. positive control (EAV, Bucyrus strain), 10. PCR marker, $100 \mathrm{bp}$ 
During 2013, 7 stallions and 14 mares were tested for the presence of anti-EAV antibodies. Compared to the year 2012, the number of examined animals was reduced ( 2 seronegative stallions were sold and 6 seronegative mares were sold or not included anymore into the breeding process). The stallions, that were seropositive in 2012, also reacted positively in 2013. However, antibody titre values changed and were $2 \log _{2}$ in 2 stallions, whereas 5 and $8 \log _{2}$ were detected in 2 stallions. The presence of anti-EAV antibodies were confirmed in the same mares in 2012 and 2013, yet with somewhat lower titre values ranging from 2 to $8 \log _{2}$.

In 2013, 6 (3+3) semen samples were collected from a seropositive and a seronegative stallion (stallion № 1 and № 2, respectively). The presence of EAV RNA was confirmed by RT-PCR in all three semen samples originating from the seropositive stallion (stallion № 1), whereas the virus RNA was not detected in the samples from the seronegative animal (stallion № 2). Detection of the viral RNA by RT-PCR in semen samples is presented in Figure 1.

In 2014, 8 semen samples from the seropositive stallion (stallion № 1), which was EAV RNA positive in 2013, and 3 semen samples from the seropositive stallion (stallion № 3) were subjected to RT-PCR testing. RT-PCR results are presented in Figure 2.

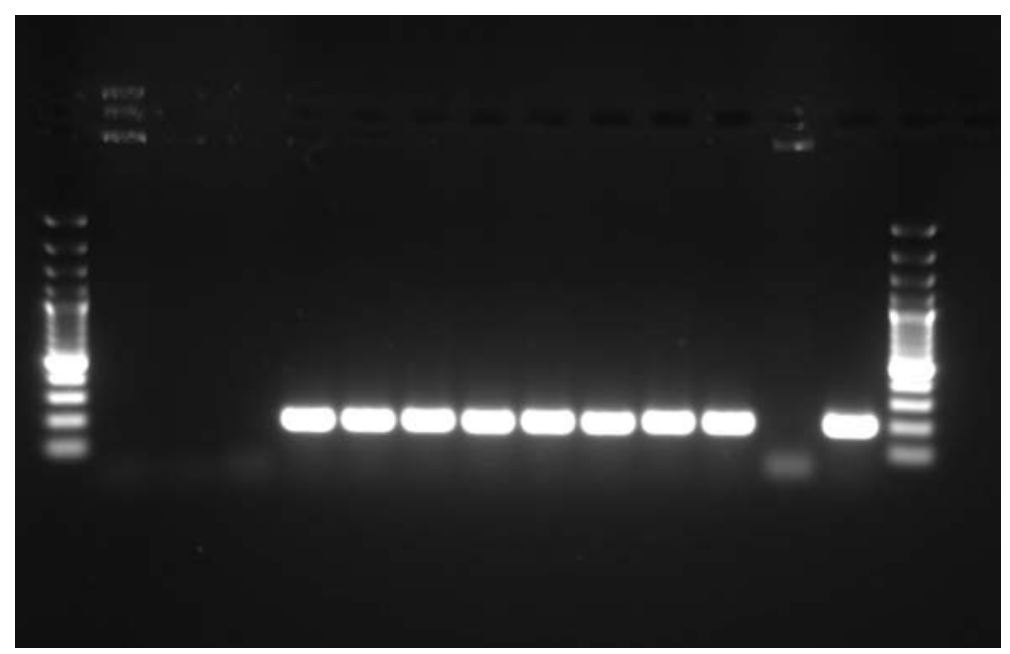

Figure 2. RT-PCR products from 11 semen samples collected in 2014 (from left to right): 1. PCR marker, $100 \mathrm{bp}$; 2. - 4. Semen samples of seropositive stallion (stallion № 3), collected: 25/04, 26/04 and 27/04; 5. - 12. Semen samples of seropositive stallion (stallion № 1), collected: 09/05, 17/05, 19/05, 22/05A, 22/05B, 23/05A, 23/05B, and 24/05; 13. negative control (water); 14. EAV - Bucyrus strain, as a positive control, and 15. PCR marker, $100 \mathrm{bp}$

Both blood sera and semen samples results from stallions, analyzed during 2013 and 2014, are presented in Table 2. 
Table 3. Results of serological testing and semen examination

\begin{tabular}{|c|c|c|c|c|c|}
\hline \multirow{2}{*}{$\begin{array}{l}\text { Year of } \\
\text { research }\end{array}$} & \multirow{2}{*}{ Stallion mark } & \multirow{2}{*}{$\begin{array}{l}\text { Antibody titre } \\
\qquad\left(\log _{2}\right)\end{array}$} & \multirow{2}{*}{$\begin{array}{l}\text { No. of examined } \\
\text { semen samples }\end{array}$} & \multicolumn{2}{|c|}{$\begin{array}{l}\text { EAV finding in } \\
\text { the semen }\end{array}$} \\
\hline & & & & Positive & Negative \\
\hline \multirow{2}{*}{2013} & № 1 & 8 & 3 & 3 & 0 \\
\hline & № 2 & 0 & 3 & 0 & 3 \\
\hline \multirow{2}{*}{2014} & № 1 & 9 & 8 & 8 & 0 \\
\hline & № 3 & 6 & 3 & 0 & 3 \\
\hline
\end{tabular}

Serological testing of the mares inseminated with the semen of examined stallions, performed during 2013 and 2014, are presented in Table 3.

Table 4. Anti-EAV antibodies in the blood sera of mares inseminated with the semen of examined stallions

\begin{tabular}{cccc}
\hline \multirow{2}{*}{$\begin{array}{c}\text { Stallion } \\
\text { mark }\end{array}$} & Mare mark & Antibody finding $\left(\log _{2}\right)$ according to the year \\
\cline { 3 - 4 } & M1 & 5 & $\mathbf{2 0 1 3}$ \\
\hline \multirow{3}{*}{ S1 } & M2 & 10 & 7 \\
& M3 & 5 & 8 \\
& M4 & 6 & 5 \\
& M5 & 5 & 3 \\
& M6 & 4 & 6 \\
& M7 & 4 & 4 \\
& M8 & 4 & 5 \\
& M9 & 5 & 4 \\
& M10 & 6 & 4 \\
& M11 & 0 & 7 \\
& M12 & 0 & 0 \\
& M13 & 0 & 0 \\
\hline
\end{tabular}

In the virus isolation test, the cytopathogenic effect was not observed after three subsequent blind passages. RT-PCR testing of cell supernatant from the third blind passage of the examined semen samples was negative.

Analysis of the health status in the period 2010-2014 revealed no evidence of clinical signs of the disease in either stallions or mares. All mares have been foaled at the expected terms, whereas foals did not manifest any health problem. Massive abortions have never been recorded at this horse stable, while sporadic abortions could be attributed to either physical trauma (immediate physical contact - kicking of gravid mares) or twin-embryo pregnancies. 


\section{DISCUSSION AND CONCLUSIONS}

The presence of EAV-specific antibodies in the horse blood serum is one of the evidence of the presence of the disease, which has been confirmed also in our study by findings of high antibody titre values in breeding stallions and mares [6,12,14]. High antibody titre and seroprevalence in stallions (45\%) and mares (65\%), without clinical signs strongly suggest the long-lasting presence of the disease at a horse stable [8]. Positive RT-PCR finding of EAV in the semen of breeding stallions is the key evidence for the presence of EVA, which has been confirmed in the reports of numerous researchers $[11,14,15]$. In our study, EAV was detected by RT-PCR in all (11) tested semen samples from one (stallion № 1) of the three examined stallions, during the mating season in 2013 and 2014. The presence of the virus confirmed in all 11 semen samples, from two consecutive years, strongly suggests that some stallions can shed the virus in their semen for life, which is in agreement with already published data [11]. The virus isolation on RK-13 cell culture was not successful, which can be explained by different reasons. Some authors in their studies also detected the virus using RTPCR but have failed to isolate EAV on RK-13 cell culture [8]. RT-PCR negative result in 3 semen samples from another seropositive stallion (stallion № 3) cannot exclude the possibility of EAV shedding in the semen. This stallion most probably sheds the virus intermittently, since we have detected anti-EAV specific antibodies in the blood sera of mares inseminated with the semen of this stallion in 2012 and 2013 (Table 3). According to the guidelines by OIE Terrestrial Manual, Chapter 2.5.10, (2013) and report of Belasurya et al. (2013), seroconversion in seronegative mares 4 weeks after artificial insemination or mating indicates shedding of EAV in the stallion's semen. As expected, the presence of the virus in the semen of the seronegative stallion (stallion № 2) was not confirmed by RT-PCR and examination of blood sera of mares inseminated with his semen did not reveal seroconversion (Table 3).

The absence of clinical symptoms of EVA and particularly the absence of abortions in pregnant mares, which was established by analyzing the 5-year health status of animals at this stable, is in accordance with numerous authors that the disease can take a subclinical or clinical course depending on the immune status of the horse $[6,8,9]$. Changing of the health status in foals, manifested by "pneumo-enteric" syndrome or other EVA-associated diseases, have not been detected on this farm, which is attributed to strong maternal immunity of foals obtained by colostrums uptake [6].

Based on the presented results, we can conclude that EAV was detected in the stallion semen, which is, according to our knowledge, the first confirmation of this virus in the Republic of Serbia. Further research on this disease will be conducted with a special emphasis on the characterization of the detected virus strain, which includes sequencing and molecular typing, with the aim to investigate its biological properties and its impact on the health status of the horse population.

\section{Acknowledgement}

The research was funded by the Ministry of Education, Science and Technological Development of the Republic of Serbia, projects No TR 31084 and TR 37015. 


\section{LITERATURA}

1. Balasuriya UB, Hedges FJ, Nadler AS, McCollum HW, Timoney JP, MacLachlan NJ: Genetic stability of equine arteritis virus during horizontal and vertical transmission in an outbreak of equine viral arteritis. Journal of General Virology 1999, 80, 1949-1958.

2. Doll ER, Bryans JT, McCollum WH, Crowe MEW: Isolation of a filterable agent causing arteritis of horses and abortion in mares. Its differentiation from the equine abortion (influenza) virus. Cornell Vet. 1957, 47, 3-41.

3. McFadden, A.M., Pearce, P.V., Orr, D., Nicoll, K., Rawdon, T.G., Pharo, H., Stone, M: Evidence for absence of equine arteritis virus in the horse population of New Zealand. New Zealand Veterinary Journal 2013, 61, 5, 300-304.

4. McCollum WH, Prickett ME, Bryans JT: Temporal distribution of equine arteritis virus in respiratory mucosa, tissues and body fluids of horses infected by inhalation. Research Veterinary Science 1971, 12, 459-464.

5. Collins JK, Kari S, Ralston SL, Bennet DG, Traub-Dargatz JL, McKinnon AO: Equine viral arteritis in a veterinary teaching hospital. Preventive Veterinary Medecine 1987, 4, 389-397.

6. Balasuriya UB, Young YG, MacLachlan NJ: Equine arteritis virus, Veterinary Microbiology 2013, 167, 93-122.

7. Vaala WE, Hamir AN, Dubovi EJ, Timoney PJ, Ruiz B: Fatal, congenitally acquired infection with equine arteritis virus in a neonatal thoroughbred. Equine Veteterinary Journal 1992, 24, 155-158.

8. Szeredi L, Hornyak A, Palfi W, Molnar T, Glavits R, Denes B: Study on the epidemiology of equine arteritis virus infection with different diagnostic techniques by investigating 96 cases of equine abortion in Hungary. Veterinary Microbiology 2005, 108, 235-242.

9. Del Piero F: Equine viral arteritis. Veterinary Pathology 2000, 37, 287-296.

10. Hostnik P, Mankoč S, Toplak I, Klobučar I, Malovrh T, Grom J: Control of equine arteritis virus (EAV) on horse farm. Veterinarski arhiv 2011, 81 (2), 175-186.

11. Hans A, Gaudaire D, Manuguerra JC, Leon A, Gessain A, Laugier C, Berthet N, Zientara S: Combination of an Unbiased Amplification Method and a Resequencing Microarray for Detecting and Genotyping Equine Arteritis Virus. Journal of Clinical Microbiology 2015, 53, 1, 287-291.

12. Balasuriya UB, Snijder EJ, van Dinten LC, Heidner HW, Wilson WD, Hedges JF, Hullinger PJ, MacLachlan NJ: Equine arteritis virus derived from an infectious cDNA clone is attenuated and genetically stable in infected stallions. Virology 1999, 260, 201-208.

13. OIE Terrestrial Manual, Equine Viral Arteritis, Chapter 2.5.10. 2008.

14. OIE Terrestrial Manual, Equine Viral Arteritis, Chapter 2.5.10. 2013.

15. Echeverria MG, Pecoraro, MR, Galosi CM, Etcheverrigaray ME, Nosetto EO: The first isolation of equine arteritis virus in Argentina. Review Scientific and Technical of the Office International des Epizooties (Paris) 2003, 22, 1029-1033.

16. Lazić S, Lupulović D, Lazić G, Živulj A, Bugarski D, Petrović T: Study of the equine viral arteritis seroconversion at horse stables in the territory of Vojvodina. Archives of Veterinary Medicine 2013, 6, 2, 27 - 36.

17. Balasuriya UB, Leutenegger CM, Topol JB, McCollum WH, Timoney PJ, MacLachlan NJ: Detection of equine arteritis virus by real-time TaqMan reverse trancription-PCR assay. Journal of Virological Methods 2002, 101, 21-28. 


\title{
UTVRĐIVANJE VIRUSA VIRUSNOG ARTERITISA U SEMENU PASTUVA U REPUBLICI SRBIJI
}

\author{
LAZIĆ Sava, LUPULOVIĆ Diana, POLAČEK Vladimir, VALČIĆ Miroslav, LAZIĆ \\ Gospava, PAŠAGIĆ Enisa, PETROVIĆ Tamaš
}

U radu su prikazani rezultati ispitivanja krvnih seruma priplodnih kobila i pastuva i utvrđivanje genoma virusa virusnog arteritisa konja (EAV) u semenu pastuva. Ispitivanja su vršena na jednoj ergeli u Republici Srbiji tokom 2012., 2013. i 2014. godine. Utvrđivanje EAV vršeno je dokazivanjem antitela u krvnom serumu, virus neutralizacionim testom (VNT) i dokazivanjem virusa u semenu pastuva, RT-PCR. Na ispitivanoj ergeli u 2012. godini utvrđena je visoka seroprevalencija EAV, koja je kod priplodnih pastuva iznosila 45\%, a kod prioplodnih kobila $65 \%$, a utvrđene vrednosti titra antitela su iznosile od 2 do $10 \log _{2}$. Visoka seroprevalencija kod istih konja potvrđena je i u 2013. godini, a EAV virus je dokazan RT-PCR u svim prikupljenim uzorcima (3) semena seropozitivnog pastuva, dok u uzorcima (3) seronegativnog pastuva virus nije dokazan. U 2014. godini prikupljeno je 11 uzoraka semena od 2 seropozitivna pastuva. Virus EAV je ponovo dokazan RT-PCR u svim uzorcima (8) semena istog pastuva, u čijem semenu je ovaj virus dokazan 2013. godine, dok u uzorcima (3) semena drugog isptivanog pastuva, virus nije dokazan. U krvnom serumu kobila, koje su osemenjavane semenom seropozitivnih pastuva 2012. i 2013. godine utvrđeno je prisustvo specifičih antitela protiv EAV. 